\title{
Tackling Marine Plastic Pollution Through Source-To-Sea Approach and Circular Economy
}

\author{
A. E. Francis and S. Herat $\pitchfork$
}

School of Engineering and Built Environment, Griffith University, Queensland 4111, Australia

$\dagger$ Corresponding author: S. Herat; s.herat@griffith.edu.au

Nat. Env. \& Poll. Tech. Website: www.neptjournal.com

Received: 09-06-2020

Revised: $02-07-2020$

Accepted: 16-07-2020

Key Words:

Marine plastics

Plastic waste management

Plastic leakage

Source-to-sea approach

Circular economy

\begin{abstract}
Marine litter and associated marine pollution are becoming a complex global environmental hazard these days. Among the different faces of marine pollution, by far the largest and probably the most dangerous part is marine plastic litter. Plastic litter can be found in almost every marine environment in the world, including deep ocean beds and frozen polar ice. Unless new sustainable methods of plastic production and waste management are encouraged, marine plastic pollution will continue to pose a severe threat to the natural ecosystems of the world. In this paper, the status of marine plastic litter is reviewed using a DPSIR framework, and it is found that significant changes in the way we live and consume are needed to prevent it. A framework that combines the source-to-sea approach and circular economy is introduced as a possible solution to eliminate plastic waste from the environment as well as from the economy.
\end{abstract}

\section{INTRODUCTION}

It was during the beginning of commercial plastic production in the 1970s, scientists first recognized plastic pollution in marine environments. The first reports which pointed out the threats of plastic litter on marine life such as the presence of polystyrene spherules in the marine waters of southern New England (Carpenter et al. 1972) and the entanglement of northern fur seals on trawl nets (Fowler 1987) did not gain enough attention from the research community at the time (Andrady 2011, Ryan 2015). Within just a few decades since then, plastic debris has made its entry to almost every part of the environment. It is estimated that more than 5.25 trillion plastic particles with a weight of around 268,940 tons are currently floating in the world's oceans (Eriksen et al. 2014). The presence of plastics is not limited to places where there is direct human contact but, it has been found even in the world's largest and only remaining pristine regions, like the Arctic and the Antarctic. Besides, plastic litter in these remote areas reflects the pollution levels of the nearby waters (Bergmann et al. 2013, Eriksson et al. 2013). Similarly, Henderson Island in the South Pacific, regarded as the most remote island of the world, once had an average of 671.6 debris items per square meter on its beaches, which was the highest density of plastic litter reported in the world (Lavers \& Bond 2017).

Even though there is no direct relation between litter density inland and seafloor, research shows that materials that are commonly found inland are also common on the seafloor. Therefore, knowing the common waste materials generated inland allows preventing its mismanagement from the production stage and thereby to eliminate marine plastic litter (Roman et al. 2020). However, the majority of current methods to reduce marine plastic problems focus either on one stage of the problem or on one single sector, which is responsible for marine plastic pollution. These strategies often end up as unsustainable and less effective due to the lack of understanding about how natural ecosystems are linked and also due to limited cooperation within the governing system. Therefore, measures that can address the root causes of the issue by connecting and engaging all sectors and stakeholders (formal and informal, private, and public) related to the problem are essential to make a genuine change, and it was the driver of this paper (Mathews \& Stretz 2019). Therefore, the primary purpose of this paper is to undertake a systematic assessment of the status of marine plastic litter in the world's oceans, which is done using a DPSIR framework and to develop a framework that can prevent plastic from entering the natural environment.

\section{DPSIR FRAMEWORK FOR MARINE PLASTICS}

\section{Drivers and Pressures}

'Drivers' of marine plastic pollution are initiated through different socio-economic changes happening in the society, such as increasing population, urbanization, economic 
growth, and behavioural changes. To fulfil the basic needs like food, living space, energy, and recreation of these increasing populations, governments are forced to develop new economic initiatives to improve their country's productivity. These activities can lead to the extraction of more and more natural resources, including ocean resources like oil and fisheries. Also, these drivers can cause unsustainable consumption and production patterns across all sectors of society and can generate a vast amount of mismanaged waste (Ecologic.eu 2018, Grida.no 2016, UNEP 2016). This massive rise in natural resource consumption, which is both unsustainable and inefficient, creates many 'pressures' in the environment, such as environmental pollution, declining biodiversity, and exploitation of ocean resources (Atkins et al. 2011). For example, the discharge of pesticides and nutrients from agricultural runoff or improperly treated sewage can harm small marine species like phytoplankton and seagrass. This can lead to the growth of dead zones (low oxygen or hypoxic areas) in oceans where the majority of marine life cannot survive. According to UNEP, currently, around 500 dead zones spreading across
2,45,000 square kilometres are present in the world's oceans. Moreover, plastic pollution made several changes in the aquatic food webs like the rapid multiplication of bacteria, a decline in fish numbers, and the spreading of diseases (Unesco.org 2017).

\section{State}

Studies show that coastal environments across the world are in a state of deterioration due to changing environmental situations over the past few decades. Plastic debris can be found almost everywhere including beaches, surface waters, throughout the water column and even with benthos as shown in Fig. 1 (Wright et al. 2013) and can make changes in the 'state' of the oceans such as declination of water quality and ocean warming (Atkins et al. 2011).

\section{Plastics in Water Bodies}

In marine waters, plastic debris is distributed among five different sections: coastline, upper or surface ocean, the main water column, the seabed, and the biota. Transfer of

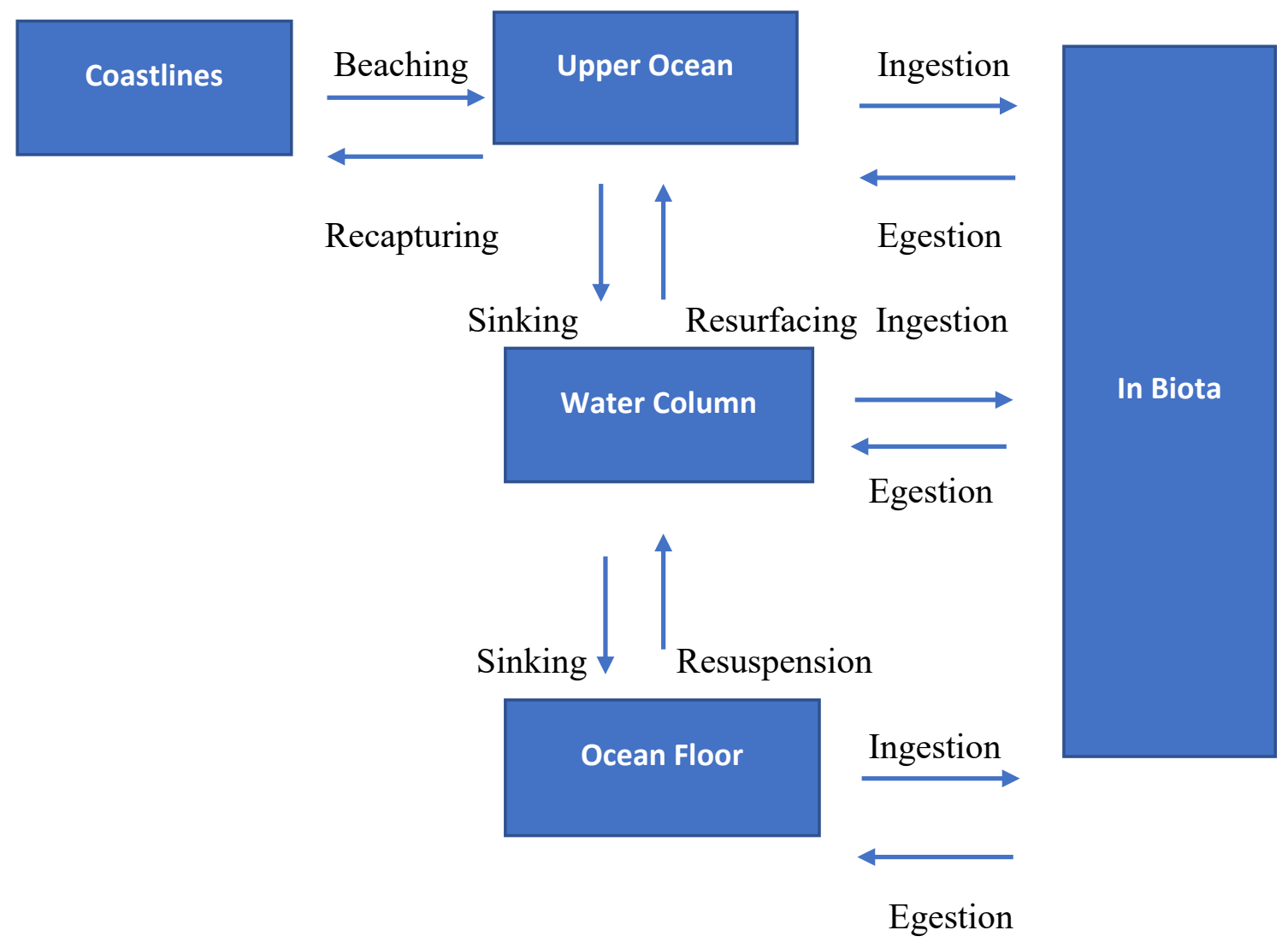

Fig. 1: Distribution of plastics in the marine environment (GESAMP 2016). 
plastics between each of these compartments can occur because of natural activities like wind, rainfall, wave action, presence of land and sea-based sources of pollution as well as the exposure of the coastline. Characteristics like density, size, and shape of particles also play crucial roles in the spreading of plastics through marine environments. Even though plastics are usually buoyant, in a marine context, plastics can be positively, neutrally, or negatively buoyant. The positively buoyant ones accumulate near ocean surfaces while negatively buoyant sink to the seabed as they are denser than water. Besides, attachment and growth of fouling and sessile organisms can also cause plastics to sink, extending debris presence throughout the water column (UNEP 2016, Bonanno \& Orlando-Bonaca 2018). The major plastic polymers present in oceans are listed in Table 1 .

\section{Plastics in Beaches, Shorelines and Sediments}

Plastic debris found in the shores is usually a mixture of particles from local sources and those that have been reached the place by ocean currents and wind. Tourism activities and other beach use, influence the type and amount of plastic litter found on a particular beach or shoreline. In addition, places with high concentrations of floating debris called 'hot spots' can be found in marine waters, which is adjacent to high coastal populations with improper waste management methods. Natural factors like rainfall, storm, and tsunamis can also lead to the unexpected accumulation of massive amounts of plastic debris in beaches and shorelines (GESAMP 2016, UNEP 2016, Li et al. 2016).

Debris can also find in sediments of shallow marine environments as well as in ocean depths. In shallow environments, debris is accumulated in sediments and can resuspend by the action of tides, waves and ocean currents, and as a result, they can distribute throughout the water column, whereas in the ocean depths sediments can be a permanent sink for plastic debris (Bonanno \& Orlando-Bonaca 2018, UNEP 2016).

\section{Impact}

The potential impacts of marine plastics can be mainly classified into ecological, economic, and social (Gall \& Thompson 2015, Unesco.org 2017) and are briefly explained below.

\section{Ecological Impacts}

Ingestion and entanglement: According to studies, ingestion and entanglement already affected more than 800 marine species globally, including around one-third of the marine turtles and nearly half of all seabirds (CSIRO 2019). Among them, seabirds seem to be particularly susceptible as they confuse tiny particles of plastics with prey and swallow them. The presence of microplastics in the guts of many dead sea birds such as Northern Fulmar and Laysan Albatross had exceeded the environmental quality put forward by OSPAR and reveals the increasing levels of plastic ingestion among birds. Pieces of evidence also show that these polluted marine invertebrates can transfer microparticles to higher predators such as great skua by acting as a pathway (Trevail et al. 2015, UNEP 2016, Wright et al. 2013). Ingestion of plastic debris also facilitates the transport of toxic chemicals into marine species either through the release of chemicals present in plastics from manufacturing processes such as plasticizers or through the accumulation and following release of pollutants such as PBTs and POPs from surrounding seawater (Lusher et al. 2013, UNEP 2016).

Accumulation of microplastic particles in marine animals can cause many health problems such as blockages in the digestive system, starvation, and physical deterioration, which eventually results into a lack of reproductive fitness, weakness in feeding ability, reduced predator avoidance, and even drowning (Wright et al. 2013). In addition to the internal accumulation of debris, external adsorption of plastic particles specifically nanoparticles may obstruct algal photosynthesis by physically blocking air and sunlight while

Table 1: Major plastic polymers present in oceans, their density and field of application (Emmerik \& Schwarz 2019).

\begin{tabular}{|llll|}
\hline Polymer & Density $\left(\mathrm{g} / \mathrm{cm}^{3}\right)$ & Major field of application \\
\cline { 2 - 3 } & Min & Max & \\
\hline Polyethylene & 0.91 & 0.97 & Packaging \\
Polypropylene & 0.9 & 0.91 & Many applications mainly packaging \\
Polyester & 1.24 & 2.3 & Textiles \\
Polyethylene terephthalate & 1.37 & 1.45 & Packaging \\
Polystyrene & 1.01 & 1.04 & Packaging \\
Expanded polystyrene & 0.016 & 0.640 & Food packaging, construction material \\
Polyvinyl chloride & 1.16 & 1.58 & Building and construction \\
Polyamide (Nylon) & 1.02 & 1.05 & Automotive, textiles \\
\hline
\end{tabular}


increasing reactive oxygen species production (Bhattacharya et al. 2010, Prata et al. 2019)

At the same time, entanglement in plastic debris mainly affects higher taxonomic groups in different extents, causing chronic and acute injuries or sometimes death (UNEP 2016). Marine animals like dolphins, seals, sea lions, sea turtles, and even whales and sharks can become trapped in marine debris as they swim or while on the beach (NOAA Fisheries 2017). Entanglement in ALDFG or ghost fishing significantly reduce the animal's mobility and can also cause serious physical injuries and infections as the gear and other pieces of equipment cut into their body. Entangled animals may also become less capable of avoiding other obstacles like they usually would, thereby increasing the risk of accidents like vessel strikes. If the gear and nets are too large or heavy, it may result in sudden drowning of smaller marine animals while larger animals can, in most cases, drag or remove the gear or parts of it; however, they do face risks such as infection and exhaustion. Many studies recognized entanglement as the principal cause of human-created mortality in marine species especially among whale species like humpback whales, right whales, and gray whales (Australia State of the Environment Report 2017, NOAA Fisheries 2017)

Habitat loss and introduction of invasive species: Plastic debris can cause scouring, smothering, and breaking of marine habitats, which are the foundation of marine ecosystems and are vital for the existence of all marine species (Impacts | OR\&R's Marine Debris Program 2020). Among these, coral reefs are most vulnerable to damage by plastic debris items such as lost fishing gears and ALDFG as these can get hooked on the branches of reefs and can leave significant scars on them by breaking or scratching. Besides, the movement of these nets and ropes can cause abrasion, fragmentation, dislodging, direct suffocation and shading of fouled species colonies which in turn make the corals prone to diseases by facilitating colonization of pathogens (Lamb et al. 2018, The NOAA Marine Debris Program 2018, UNEP 2016, Vegter et al. 2014).

Plastic debris can also accumulate on mangrove forests as they act as a partial sink for plastics (UNEP 2016). Besides, these materials can provide new safe habitats for the growth and survival of foreign species, which can eventually become invasive and aggressive and can harm the local flora and fauna (Gall \& Thompson 2015). Moreover, plastic materials can also lower the numbers of invertebrates in marine waters by significantly decreasing the levels of oxygen in sediments (Ec.europa.eu 2019)

Rafting: In the context of marine plastic pollution, rafting can be defined as the transport of organisms attached to debris, which acts as a new artificial substrate in addition to natural materials. This macro and microplastic debris with much higher longevity can host an extensive collection of non-indigenous species like crustaceans, bryozoan, and cephalopods by creating novel habitats. Once colonized by marine biota, these floating debris act as a potential transport vector and facilitate the spreading of the associated organisms at different spatial scales. These debris items usually travel very long distances and reach shorelines where it is foreign, thus disturbing the local fauna and flora (Kiessling et al. 2015, Impacts | OR\&R's Marine Debris Program 2020, UNEP 2016). Sometimes they can even reach gyres and combine with eddy currents that can carry these strange hitchhikers across the oceans. Various studies have found that the ability of biota to travel has been doubled with the presence of marine litter, making marine debris a reservoir of potential biological invasions (Garcia-Vazquez et al. 2018).

\section{Socio-economic Impacts}

Human health and food safety: Seafood is the major source of protein for around two-thirds of the global population, and contaminating these food sources leads to many chronic and acute health issues. Tiny fragments of plastics can reach human bodies through the consumption of seafood, particularly the whole animal foods like sea cucumbers and sea urchins and filter-feeders such as oysters and mussels as plastic often accumulate in the digestive tracts of these organisms (Murano et al. 2020, Smith et al. 2018). Besides, a wide variety of commercial species like shrimps, shellfish, and other smaller fish types are also found to be polluted with microplastics (UNEP 2016). Also, many studies from different countries found the presence of microplastics in sea salt samples with few studies showed a rate of $94 \%$ of the total sample of salt products tested contained microplastics. Furthermore, there is evidence for the presence of tiny fragments of plastics in beer and tap water which proves that plastics can reach the human body through the food chain (IUCN n.d., Iñiguez et al. 2017, Yang et al. 2015, Lee et al. 2019).

Usually, smaller ones like nano plastics and microplastics cause more significant damage to health due to its smaller size, the larger surface to volume ratio, and high reactivity. The most common health impacts of these ingested plastic fragments include inflammatory issues, obesity, cancer, and alteration in chromosomes, which can cause infertility (Smith et al. 2018, Sharma \& Chatterjee 2017). Furthermore, nanoparticles can penetrate all human organs, including the placenta and brain, and can cause severe health issues. Endocrine disruption chemicals which have been used extensively on the plastic production processes are another concern (UNEP 2016). 
In addition, floating debris possess navigation hazards to ships, boats as well as to scuba divers and surfers. Incidents of injuries and drowning of scuba divers due to entanglement in discarded fishing nets and ropes have found several times in the history of marine pollution (UNEP 2001). Moreover, collisions with partially submerged or floating objects like plastic shipping containers can lead to failures and collapse of ships and boats. In 2005, the USA coastguard reported 269 accidents, which caused 116 injuries and 15 deaths because of collisions with submerged objects in oceans (UNEP 2016).

Loss of income: Marine plastics are an eyesore, detrimental to the beauty and attractiveness of marine environments, thereby negatively affecting maritime activities like recreation, tourism, and shipping. Debris can negatively influence recreational activities like snorkelling and diving, as well as pollutes propellers and jet intakes of recreational boaters and affect recreational fishers by polluting catch or restricted catch. As a result, tourists tend to avoid polluted beaches, and this reduction in visitor numbers can significantly reduce revenues from the tourism industry resulting in a loss of income and reduction in local job opportunities. These effects can be quite severe in places where local economies are dependent too much on the tourism sector as in Hawaii, Bali, and the Maldives. In addition, loads of marine plastics in oceans can significantly reduce the benefits provided by various marine ecosystem services. A survey conducted in 2011 estimated a reduction of $1-5 \%$ of marine ecosystem services, which caused a loss of 500-2500 billion USD to the economy due to loss of benefits obtained from these services (Beaumont et al. 2019). Another concerning issue is the clean-up costs of this accumulated debris. Beach clean-up programs and vessel repairing alone cause an annual loss of around one billion dollars in the Asia Pacific (Cbd.int 2016, UNEP 2016) while some power companies in Europe spent more than 75000 USD annually to clear debris from their water intake screens (Vegter et al. 2014). In the fisheries industry, plastic contamination lowers the value of seafood, along with increasing the time and expenses required to clean and repair fishing nets (UNEP 2016).

\section{Responses}

Marine plastic pollution can be reduced significantly with proper measures and laws in place and its strict and careful implementation. This can be done in three main ways: a) restricting the use of conventional plastics through political level initiatives and actions such as imposing bans on single-use plastics and forming efficient waste management systems; b) provide economic benefits for reducing traditional plastic usage along with incentives to promote alternative materials; c) facilitate more research on the production and consumption of alternative materials. All these measures along with proper awareness and education can make a real difference in making marine plastic pollution under control (Filho et al. 2019)

Addressing the issues of marine plastic debris is a significant priority in recent years as the awareness about the issue and the political will to tackle this has increased. Accumulation of plastic debris in coastal environments and habitats has been pointed out as a huge waste problem by the UN Environment Assembly (Ec.europa.eu 2019). Many programs and tools are developed and initiated globally and regionally to mitigate these problems. In 2005, the United Nations General Assembly identified the problem of marine litter in its Resolution A/60/L.22- oceans and Laws of the Sea and called for global, national, and regional actions to tackle it. Besides, Goal 14 of the Sustainable Development Goals is aimed at preventing marine pollution and has specific targets, and the important ones are shown in the Fig. 2 (UNEP n.d.).

To achieve these targets following initiatives are taken

- 109 countries committed to a Global Programme of Action for the Protection of the Marine Environment from Land-Based Activities

- More than 143 countries have joined 18 Regional Seas Conventions and Action Plans

- 30 countries already joined the \#CleanSeas campaign on marine litter

Another important action taken to prevent marine plastics is the Clean Seas program of UNEP launched in February 2017. This program collaborates private sectors, government, civil societies, and the public to tackle the root causes of

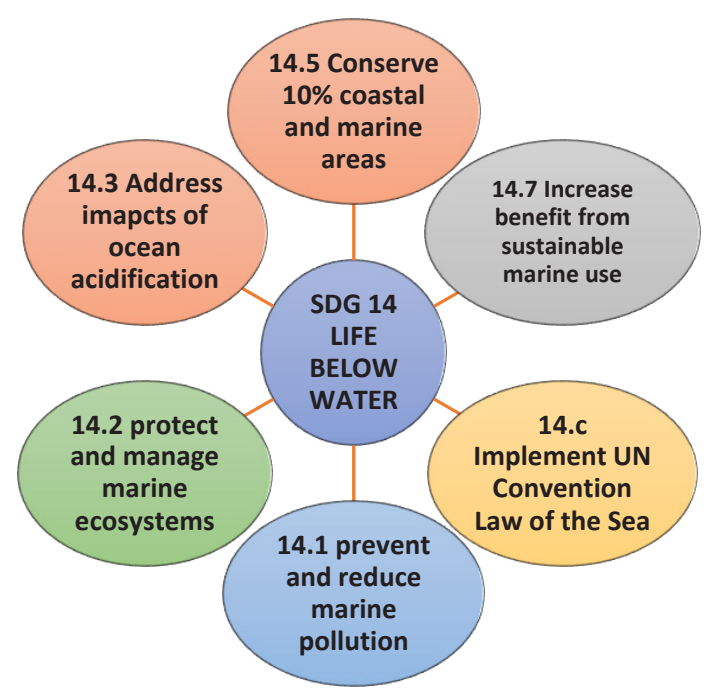

Fig. 2: Main targets of SDG 14 (UNEP n.d.). 
marine litter pollution, such as the production and use of single-use or non-recoverable plastic products (Clean Seas 2019).

Some of the other major global and regional initiatives and frameworks adopted to tackle marine pollution are listed below.

\section{International Agreements}

- International Convention for the Prevention of Pollution from Ships (MARPOL), 1973

- UN Convention on the Law of the Sea (UNCLOS), 1982

- Basel Convention on the Control of Transboundary Movements of Hazardous Wastes and their Disposal, 1989

- London Dumping Convention on the Prevention of Marine Pollution by Dumping of Wastes and Other Matter, 1996

- UN General Assembly Oceans and the Law of the Sea, 2005

- UNEP/IOC Guidelines on the Survey and Monitoring of Marine Litter, 2009

- Honolulu Strategy, March 2011

\section{Regional Agreements}

- Barcelona Convention, 1976

- East Asian Seas Action Plan (COBSEA), 1981

- Cartagena Convention, 1983

- Northwest Pacific Action Plan (NOWPAP), 1994

- Nairobi Convention,1996

- Helsinki Convention

- Strategic Approach to International Chemicals Management (SAICM), 2006

- European Marine Strategy Framework Directive, 2008

- OSPAR Convention for the Protection of the Marine Environment of the North-East Atlantic (Lloyd-Smith \& Immig 2018, Tiquio et al. 2017, UNEP 2016, Un.org 2016)

In addition to this, most recently in G7 and G20 summits and in the Annual Meeting of World Economic Forum at Davos 2020, the member nations made many commitments to reduce plastic usage and to prevent ocean pollutants.

\section{SOURCE-TO-SEA APPROACH WITH CIRCULAR ECONOMY}

Prevention and management of plastic litter require explicit knowledge about its sources, causes, and its impacts on life and the environment. By understanding the social and economic effects of ocean plastic pollution from its sources to the final point, policymakers can develop deeper and systemic changes that reach beyond traditional boundaries by linking land, freshwater, and marine systems together. Frameworks that include river basins are essential to identify the hotspots of leakage, which is essential to prioritize locations and types of interventions needed to prevent it (SIWI 2019). A Source-to-Sea approach combined with Circular Economy principles, bring together the upstream and downstream stages of marine plastic pollution and develop strategies to solve the issue from the base level. River basins play the central part of this framework, as keeping plastics away from waterways can prevent a vast amount of plastic entering the oceans. This framework, which can combine with existing policies and strategies, also addresses behavioural changes from individual to a global scale by creating conditions to facilitate this change (Fig. 3) (Mathews \& Stretz 2019).

\section{The Source-to-Sea Approach}

\section{Major Definitions}

Source-to-Sea System: A source-to-sea system, as shown in the Fig. 4, mainly consists of the following segments:

- the area of land which is drained by a river

- the river basin

- linked aquifers and downstream receivers which includes estuaries and deltas

- coastlines and nearshore waters

- the adjoining sea and the continental shelf

- the open ocean

On a larger scale, a source-to-sea system may also include a sea and its complete drainage area, which may consist of more than one river basin (Mathews \& Stretz 2019).

\section{Source-to-Sea Key Flows}

The source-to-sea system is connected by six main flows from land systems to open oceans which are shown in Fig. 5. Changes happening in each key flow can alter the state of other segments as well as the first five key flows join to shape the ecosystem services that the source-to-sea system delivers (Mathews \& Stretz 2019, Granit et al. 2017).

Six steps in the source-to-sea approach: This six major steps in the approach (Fig. 3) are briefly explained below.

\section{Step 1: Characterize}

The first step is to recognize the different sources, types, 


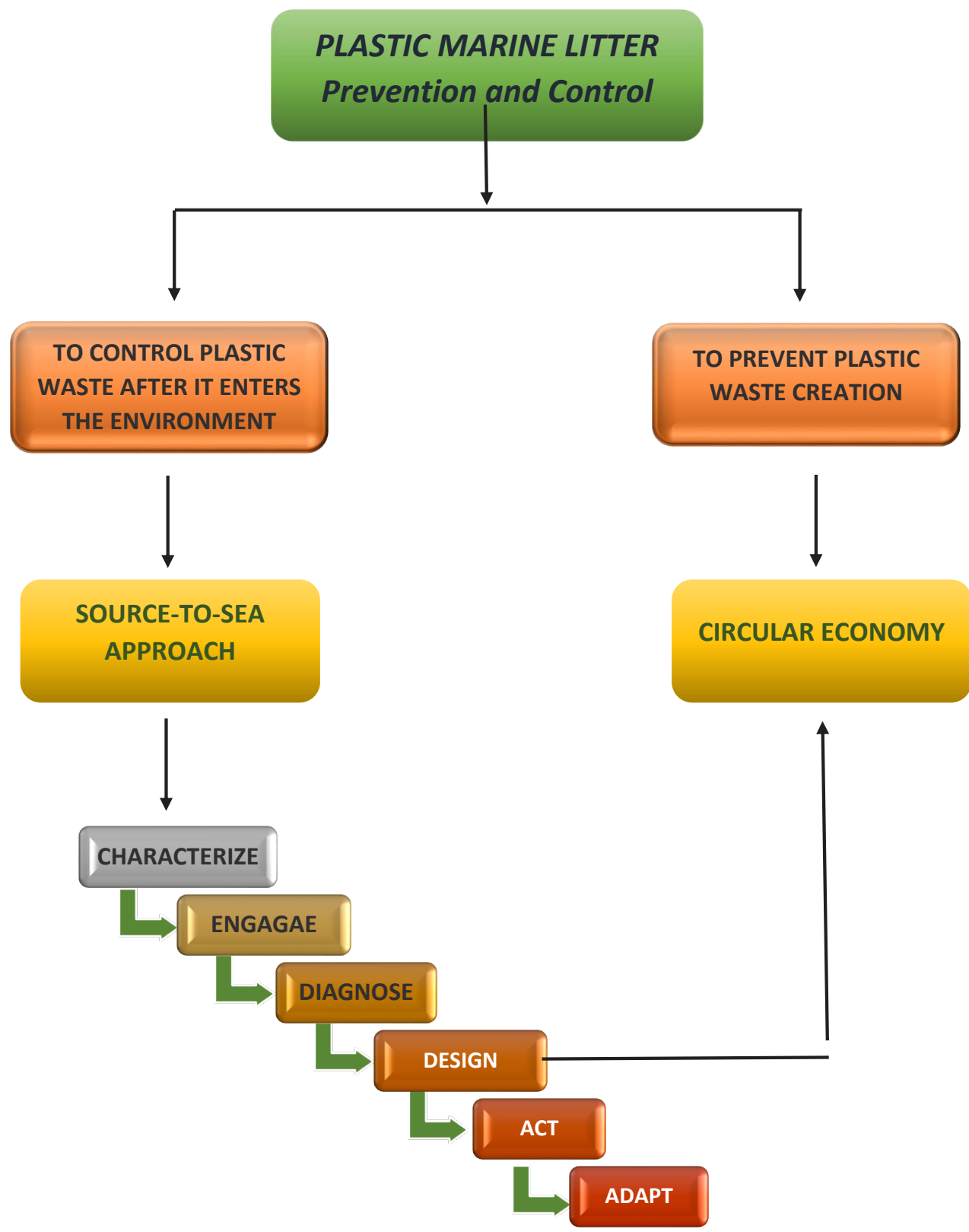

Fig. 3: The proposed framework (Mathews \& Stretz 2019).



Fig. 4: A source-to-sea system (Mathews \& Stretz 2019). 


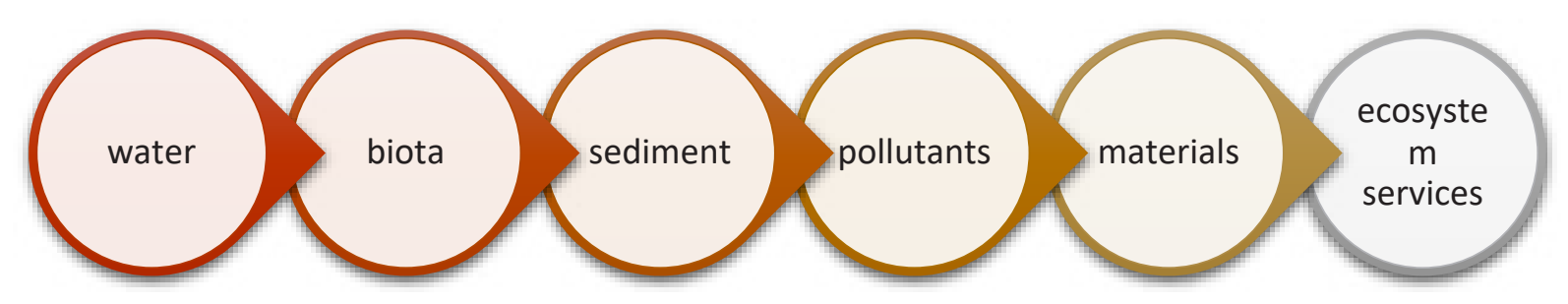

Fig. 5: Six main key flows in the source-to-sea system (Mathews \& Stretz 2019).

behaviour, and impacts of plastic waste in freshwater resources as well as in marine environments. As each source requires various measures to adopt and involve different sectors and governance structures, understanding the sources and its routes early on is vital for the successful implementation of this approach. Therefore, understanding the key flows and selecting priority flows which need action is the first phase of this step. Flows can be prioritized by analysing its character in the system, examining how they can be changed, and finding the possible impacts of these changes on the source-to-sea system. Once the key flows to be addressed are prioritized, the next step is to define the system boundaries of the project, which is essential for the following stages. Depending on the geographical locations of sources and their impacts, the geographical scope of a system can range from the local community to the global level (Mathews et al. 2019).

\section{Step 2: Engage}

In this step, the main stakeholders related to the project from local to global levels are identified, and a plan is made to engage and build partnerships with them. These partnerships with various stakeholders can help in developing a 'solution space' which brings together a wide range of participants who can provide ideas, solutions, political support, and financial help to achieve the goal, which is to prevent plastic litter. This stakeholder list and engagement plan may contain groups that are not previously considered. For instance, an ocean-focused pollution project may initially consider only ocean clean-ups and ALDFGs, but, in a source-to-sea approach, this same project take account of all upstream factors such as land-based sources as well as all sectors along with the subsequent transport of pollutants through waterways and finally into oceans (Mathews \& Stretz 2019, Mathews et al. 2019).

In this framework, there are five major types of stakeholder groups, as described in the Table 2. Bringing together all these five groups from across the source-to-sea system can show paths to new ideas, opportunities, and solutions to tackle marine plastic pollution.

\section{Step 3: Diagnose}

In this step, the current system of governance for the prevention of marine plastic litter such as agreements, laws, regulations, policies, plans, procedures and the institutions (community-level groups, local, national, regional or global institutions) that deliver them are examined in order to find drawbacks and limitations. Gaps in the existing system are figured out, and the failures are analysed carefully. To prevent marine plastic pollution, a governance system that acts on the individual, local, national, and global levels as well as address different stages of plastic, from production, to retail, consumption, collection, and disposal are essential. The importance of improving product designs by changing towards a circular economy can be understood in this step (Mathews \& Stretz 2019).

Table 2: Types of stakeholders (Mathews \& Stretz 2019).

\begin{tabular}{|c|c|}
\hline Stakeholder Type & Role \\
\hline Primary Stakeholders & $\begin{array}{l}\text { - Those who are affected by plastic waste } \\
\text { and will benefit from its prevention } \\
\text { - E.g., fishermen and communities adja- } \\
\text { cent to waterways }\end{array}$ \\
\hline Targeted Stakeholders & $\begin{array}{l}\text { - Those who are responsible for plastic } \\
\text { leakage. } \\
\text { - Includes producers of raw materials, } \\
\text { producers, retailers, and consumers of } \\
\text { plastic products and materials; waste } \\
\text { managers and recyclers of plastic } \\
\text { materials. }\end{array}$ \\
\hline Enabling Stakeholders & $\begin{array}{l}\text { - Individuals, institutions, and organi- } \\
\text { zations that enable opportunities for } \\
\text { behavioural changes to occur and help } \\
\text { to last over time. }\end{array}$ \\
\hline Supporting Stakeholders & $\begin{array}{l}\text { - Financiers or development partners } \\
\text { - Provide funding, strengthen political will } \\
\text { and advise for change }\end{array}$ \\
\hline External Stakeholders & $\begin{array}{l}\text { - Those who are not included in the system } \\
\text { boundary but have common interests } \\
\text { and their advocacy can increase attention } \\
\text { and awareness globally } \\
\text { - E.g., concerned persons and private } \\
\text { organizations. }\end{array}$ \\
\hline
\end{tabular}




\section{Step 4: Design}

Here, a program or a project is designed for the desired outcome, which is preventing plastic litter. For the effective implementation of the project, a theory of change that clearly defines intermediate steps to reach the goals needs to be developed. This theory of change describes the observed causes of the issue and predicted relationships between project or program activities as well as the desired outcomes for the project. During the development of the theory of change, it is important to consider four orders of the outcome, which can help to arrange the design of new strategies.

- First-order Outcomes: Enabling conditions that assist behavioural change of the targeted stakeholders found in step 2. This includes policies, laws, regulations, and financial support for preventing plastic pollution, to promote a strong market for recycled products as well as to develop a circular economy for plastics.

- Second-Order Outcomes: Required changes identified in step 3 to achieve benefits for the primary stakeholders as well as to accomplish other desired outcomes. This includes a reduction in plastic consumption, improved waste segregation and disposal, and increased demand for repaired and recyclable products.

- Third Order Outcomes: Denotes the improvements and changes happening in the state of the source-to-sea system because of preventing waste leakage and thereby restoring priority flows that identified in Step 1. This includes significant stress reduction in the riverine and marine environments as well as inland systems, which result in improved social, economic, and environmental conditions.

- Fourth Order Outcomes: Represents the long-term effects such as sustainable development and green growth achieved through the effective application of the intervention strategies (Mathews et al. 2019' Mathews \& Stretz 2019).

A theory of change that gives attention to all of these order of outcomes can connect all the enabling conditions needed, such as finance, infrastructure, and governance with the behaviours and practices required to change with the long term effect, which is to prevent plastic leakage into the river basins. It is easier to develop interventions by analysing these links (Mathews \& Stretz 2019).

The idea of a circular economy can link into the sourceto-sea approach at this stage. When the source-to-sea approach pays particular attention to control plastic waste once it has already created and entered the natural environments, a circular economy, on the other hand, aims at preventing the generation of plastic waste itself. Linking these two approaches presents the greatest opportunity to eliminate marine plastic pollution from its root causes (Mathews \& Stretz 2019). The concept and applications of the circular economy are explained in detail in the last section.

\section{Step 5: Act}

The financing strategy and the implementation plan for the project are developed in this stage. Hence, this step is about taking action by funding and implementing source-to-sea strategies and putting the project into practice. The significant outcomes expected from this step are developing a funding and implementation plan with the following factors:

- Public or private sources through different mechanisms.

- Linking source-to-sea priorities into public sector action plans and budgets to secure long-term financing

- Actions were taken to develop multi-sectoral engagement in the project to expand opportunities

- Finding the crucial sectors to focus on

- A risk assessment and mitigation plan

- A timeline for the implementation of the plan (Mathews et al. 2019).

\section{Step 6: Adapt}

The Source-to-Sea and Circular Economy framework (Fig. 6) is a cyclical process, and therefore, the final stage of this framework is continuous monitoring and assessment of the plan, which circles back to Step 1. By continuously evaluating outcomes of the project, the engaged stakeholders can identify any failures and can make needed changes or can find new priority flows to tackle the problem. This adaptive management cycle is crucial for the success of the project, especially in a source-to-sea approach, which includes different sectors and stakeholders. Without proper monitoring, the effect of actions in one segment of the system on another might be difficult to understand fully.

\section{Circular Economy}

Still now, the world's ever-growing economy mainly follows the traditional linear chain of the "take-make-use-dispose" system, which possesses substantial environmental and economic drawbacks (Ellen MacArthur Foundation 2017). In a linear economy, every product is bound to reach its end of life and involves huge resource losses and waste production (Ellen MacArthur Foundation 2013). However, during the past few years, there is an increasing recognition among industries and countries that resource efficiency and its availability are crucial for future economic competitiveness and resilience, and this resulted into a fundamental rethinking 


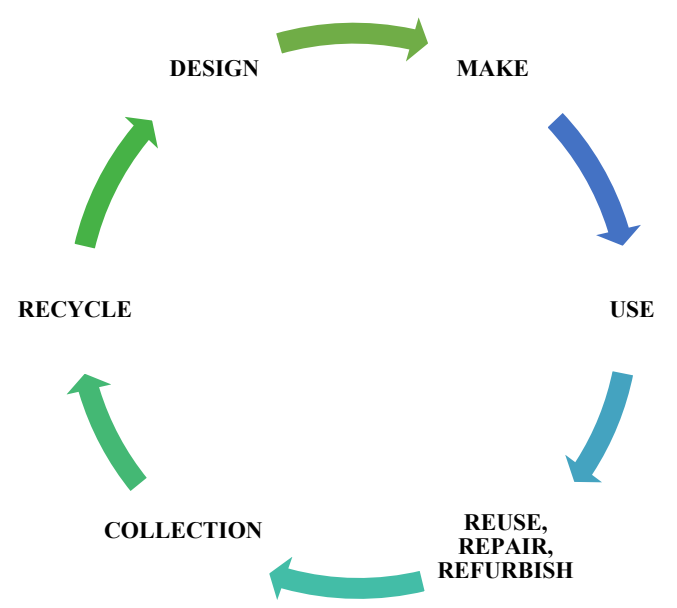

Fig. 6: A simple circular economy model (European Commission 2014).

on the current ways of resource use and methods of production (Preston 2012).

The concept of Circular Economy (CE), in which new products are either made from materials that are sourced from old products or designed in a way that each of its parts can be repaired, recycled or upgraded resulting in zero residual waste can be identified as a solution to this fast-growing resource crunch (Winans et al. 2017). By using the so-called 'wastes' as resources for other products and processes, a CE model produces nothing to throw away, instead give rise to plenty of resources to use continuously in different ways (News European Parliament 2018)

By designing out waste, CE put forward a complete change in the way things are made until now. As opposed to that of a linear model, sustainability and closed-loop thinking should be the key areas for industries and business models which plan to follow a CE, and its implementation needs strong cooperation between consumers, manufactures, businesses, and governments (Barra \& Leonard 2018). Table 3 shows six major action areas for companies and governments to shift to a CE, known as the ReSOLVE framework.

By eliminating waste from the industrial chain through recycling, repairing, and reusing, the value of products and resources are maintained in the economy at its highest utility, thereby maximizing material service per resource input (Barra \& Leonard 2018). This, in turn, pushes waste up to the waste management hierarchy and leads to improved resource efficiency and security by reducing the extraction and import of new raw materials (ESA 2017). Hence, circular economy principles have the potential to decouple rising economic development from growth in resource consumption. According to studies, transitioning towards a
Table 3: The ReSOLVE framework (Ellen MacArthur Foundation 2015).

\begin{tabular}{|ll|}
\hline The ReSOLVE & Framework \\
\hline Regenerate & - Use renewable energy sources and materials \\
& - Retrieve, maintain and restore damaged ecosystems \\
& - Give back retrieved biological resources to nature \\
Share & - Share goods and properties \\
& - Reuse or buy second-hand items \\
& - Increase the life span of materials through mainte- \\
& nance, upgrading and designing for durability \\
Optimise & - Improve product performance and efficiency \\
& - Eliminate waste from production processes and from \\
& supply chain \\
Loop & - Remanufacture or recycle products and its parts \\
& - Promote anaerobic digestion \\
& - Extract biochemicals from organic waste \\
Virtualise & - Dematerialize directly (e.g., travel, books, DVDs) \\
& - Dematerialise indirectly (e.g., online shopping) \\
Exchange & - Use new processes and technologies like 3D printing \\
& - Choose new products and services such as multimodal \\
& transport
\end{tabular}

circular economy can reduce new material consumption by more than $50 \%$ by 2050 (News European Parliament 2018, Romero-Hernández \& Romero 2018). In addition, CE also bring benefits such as boosting economic growth, stimulate innovation, create jobs, increase competitiveness as well as significantly reduce environmental problems including carbon emissions (Ellen MacArthur Foundation 2015, News European Parliament 2018)

\section{Circular Economy and Marine Plastic Pollution}

When it comes to marine plastic pollution, even if various countries and regions implement united abatement efforts to decrease the plastic leakage, the volume of plastic reaching the oceans would be most likely to stabilize rather than decline, indicating the total volume of marine plastics will continue to increase. To change this, new strategies and efforts which aim in long term solutions like the adoption of CE principles on plastic production and consumption are essential (Ellen MacArthur Foundation 2015). This can achieve in six general ways; reduce raw materials, redesign products for reuse and recycling, eliminate single-use plastics, reuse products, recycle products or its parts to avoid plastic waste and recover resources from the end of life products (UNEP 2016).

\section{Methods of Application}

Linking CE principles into plastics not only prevents the entry of plastic waste into riverine and marine environments but also maximizes the resource value of plastic materials through recycling, reusing, and redesigning. CE can apply to the world of plastics in different ways such as: 
- Produce plastics from alternative renewable feedstocks such as plant fibres

- Develop new techniques and processes to make products with less plastic content

- Design plastic products to reuse, recycle or repair easily

- Develop technologies to effectively reprocess used plastics and encourage innovations to find environmentally friendly alternatives to plastics.

- Initiate extended producer responsibility (EPR) to make the producer completely responsible for their products, even after its use.

- Develop vigorous information platforms to acquire details about the composition of plastic products as well as to trace the movement of plastic resources within the economy.

- Improve awareness among consumers on sustainable consumption and waste management.

Among this, the key to the successful implementation of $\mathrm{CE}$ is efficient design instead of trying to deal with the waste after it created. The main things to be considered in the design stage of plastic products are

- Use of less toxic, renewable, bio-degradable, or compostable materials as raw materials for plastic products

- Minimize material used to reduce waste and design using single or a few numbers of polymers that are easy to separate during recycling

\section{Other Possible Solutions for Plastic Waste Management}

Plastic waste is a global problem which is increasing every day. In addition to CE principles, several other approaches and solutions can be implemented to reduce plastic waste. An efficient waste management system as in Japan is one of the best possible solutions to the leakage of plastic waste. By increasing waste segregation, collection and recycling activities, a proper waste management system can capture plastic materials before it reaches the environment and becomes a problem (UNEP 2018, OECD 2018). Government policies and regulations are other possible ways of eliminating plastic waste. Many national, state and local governments are implementing bans on singleuse plastics such as plastic bags and plastic packaging, particularly from styrofoam. Providing financial assistance in the form of incentives and funds to facilitate the use of natural materials in making bags and packaging can motivate businesses and industries to become more environmentally friendly (UNEP 2018). Polymers created from biomass such as polylactic acid (PLA), polyhydroxyalkanoates (PHA) and thermoplastic styrenic elastomers (TPS) are potential natural alternatives to single use plastic materials (UNEP 2018). However, additional research is needed in this field to examine the behaviour and impacts of these biopolymers in the environment at its end of life as well as the potential recycling options for them. Moreover, policymakers and government should give special attention to check whether products with natural materials are labelled correctly. For example, if a product is defined as biodegradable or bioplastics then they should provide the conditions under which the degradation process happens (UNEP 2018).

Another important approach to eliminate plastic waste is Extended Producer Responsibility or EPR. In this policy, producers are made responsible for the disposal and treatment of their products at the end of life. EPR can prevent plastic waste from creating as businesses will start looking for environmentally friendly product designs and facilitate better recycling options (OECD n.d.). Clean up activities such as ocean clean-ups and other remediation activities like developing devices and technologies like the interceptor to collect plastic litter from oceans help to remove plastics that are already in the environment (OECD 2018, Rivers | The Ocean Cleanup 2020)

\section{CONCLUSION}

Plastic contamination has become a severe concern in the marine environments of the world today due to rapid urban industrial transformation. Therefore, the challenge is to promote development and economic growth while keeping environmental sustainability safe and protected. A source-to-sea approach can help this to happen by linking all sectors such as land, water resources, coastal and marine management from land to freshwater to marine environments to develop solutions. This approach, along with a CE model of production and consumption, can become the best possible solution for preventing marine plastics. However, there are many novel challenges in effectively implementing the introduced framework within the current system of production and consumption, which need further research. This includes a lack of specific and standardized guidelines on how to implement the framework, how to properly recognize, categorize, and link all related stakeholders as well as lack of secondary markets for recycled goods.

\section{REFERENCES}

Andrady, A. 2011. Microplastics in the marine environment. Marine Pollution Bulletin, 62(8): 1596-1605.

Atkins, J., Burdon, D., Elliott, M. and Gregory, A. 2011. Management of the marine environment: Integrating ecosystem services and societal benefits with the DPSIR framework in a systems approach. Marine Pollution Bulletin, 62(2): 215-226. 
Australia State of the Environment Report. 2017. Marine debris. [online] Available at: https://soe.environment.gov.au/theme/marineenvironment/topic/2016/marine-debris [Accessed 16 Oct. 2019].

Barra, R. and A.Leonard, S. 2018. Plastics and The Circular Economy. Washington, DC: Scientific and Technical Advisory Panel to the Global Environment Facility.

Beaumont, N., Aanesen, M., Austen, M., Börger, T., Clark, J., Cole, M., Hooper, T., Lindeque, P., Pascoe, C. and Wyles, K. 2019. Global ecological, social and economic impacts of marine plastic. Marine Pollution Bulletin, 142: 189-195.

Bergmann, M., Lutz, B., Tekman, M. and Gutow, L. 2017. Citizen scientists reveal: Marine litter pollutes Arctic beaches and affects wild life. Marine Pollution Bulletin, 125(1-2): 535-540.

Bhattacharya, P., Lin, S., Turner, J. and Ke, P. 2010. Physical adsorption of charged plastic nanoparticles affects algal photosynthesis. The Journal of Physical Chemistry C, 114(39): 16556-16561.

Bonanno, G. and Orlando-Bonaca, M. 2018. Ten inconvenient questions about plastics in the sea. Environmental Science \& Policy, 85: 146154.

Carpenter, E., Anderson, S., Harvey, G., Miklas, H. and Peck, B. 1972. Polystyrene spherules in coastal waters. Science, 178(4062): 749-750.

Cbd.int. 2016. Marine Debris: Understanding, Preventing and Mitigating the Significant Adverse Impacts on Marine and Coastal Biodiversity. [online] Available at: https://www.cbd.int/doc/publications/cbd-ts83-en.pdf [Accessed 28 Nov. 2019].

Clean seas, 2019. about | Cleanseas. [online] Available at: https://www. cleanseas.org/about [Accessed 6 Oct. 2019].

CSIRO 2019. Marine debris Sources, distribution and fate of plastic and other refuse - and its impact on ocean and coastal wildlife. [online] Available at: https://www.csiro.au/ /media/OnA/Files/15-00156_ OA_MarineDebris4ppFactsheet_WEB_190405.pdf [Accessed $2 \overline{2}$ Dec. 2019].

Ecologic.eu. 2018. No More Plastics in the Ocean | Ecologic Institute: Science and Policy for a Sustainable World. [online] Available at: https://www.ecologic.eu/16131 [Accessed 5 Nov. 2019].

Ec.europa.eu. 2019. Biodegradable, oxo-degradable and compostable bags observed over three years in the sea, open air and soil. [online] Available at: https://ec.europa.eu/environment/integration/research/ newsalert/pdf/biodegradable_oxodegradable_compostable_bags_ observed_in_sea_air_soil_536na4_en.pdf [Accessed 15 Jan. 2020].

Ellen MacArthur Foundation. 2013. Towards the Circular Economy Economic and business rationale for an accelerated transition. [online] Available at: https://www.ellenmacarthurfoundation.org/assets/ downloads/publications/Ellen-MacArthur-Foundation-Towards-theCircular-Economy-vol.1.pdf [Accessed 10 Oct. 2019].

Ellen MacArthur Foundation, The McKinsey Center, NERA 2015. Delivering the Circular Economy - A Toolkit for Policymakers. Ellen MacArthur Foundation.

Ellen MacArthur Foundation, 2017. The New Plastics Economy: Catalysing Action. [online] Davos: World Economic Forum and Ellen MacArthur Foundation. Available at: <https://www.ellenmacarthurfoundation. org/publications $>$ [Accessed 6 March 2020].

Emmerik, T. and Schwarz, A. 2019. Plastic debris in rivers. WIREs Water, 7(1).

Eriksson, C., Burton, H., Fitch, S., Schulz, M. and van den Hoff, J., 2013. Daily accumulation rates of marine debris on sub-Antarctic island beaches. Marine Pollution Bulletin, 66(1-2): 199-208.

Eriksen, M., Lebreton, L., Carson, H., Thiel, M., Moore, C., Borerro, J., Galgani, F., Ryan, P. and Reisser, J. 2014. Plastic pollution in the world's oceans: More than 5 trillion plastic pieces weighing over 250,000 tons afloat at sea. PLoS ONE, 9(12): e111913.

ESA 2017. Planning For A Circular Economy. [online] Available at: $<$ http://www.esauk.org/what-we-say/publications/publicationsarchive $>$ [Accessed 8 February 2020].
European Commission, 2014. Towards A Circular Economy: A Zero Waste Programme For Europe. Brussels: European Commission.

Filho, W., Havea, P., Balogun, A., Boenecke, J., Maharaj, A., Ha'apio, M. and Hemstock, S. 2019. Plastic debris on Pacific Islands: Ecological and health implications. Science of The Total Environment, 670: 181-187.

Fowler, C. 1987. Marine debris and northern fur seals: A case study. Marine Pollution Bulletin, 18(6): 326-335.

Gall, S. and Thompson, R. 2015. The impact of debris on marine life. Marine Pollution Bulletin, 92(1-2): 170-179

Garcia-Vazquez, E., Cani, A., Diem, A., Ferreira, C., Geldhof, R., Marquez, L., Molloy, E. and Perché, S. 2018. Leave no traces - Beached marine litter shelters both invasive and native species. Marine Pollution Bulletin, 131: 314-322.

GESAMP. 2019. Guidelines for the Monitoring and Assessment of Plastic Litter in the Ocean 10 GESAMP. [online] Available at: http://www. gesamp.org/publications/guidelines-for-the-monitoring-and-assessmentof-plastic-litter-in-the-ocean [Accessed 8 Jan. 2020].

Granit, J., Liss Lymer, B., Olsen, S., Tengberg, A., Nõmmann, S. and Clausen, T. 2017. A conceptual framework for governing and managing key flows in a source-to-sea continuum. Water Policy, 19(4): 673-691.

Grida.no. 2016. Marine Litter Vital Graphics | GRID-Arendal. [online] Available at: http://www.grida.no/publications/60 [Accessed 2 Dec. 2019].

Iñiguez, M., Conesa, J. and Fullana, A. 2017. Microplastics in Spanish Table Salt. Scientific Reports, 7(1).

IUCN. (n.d.). Marine plastics. [online] Available at: https://www.iucn.org/ resources/issues-briefs/marine-plastics [Accessed 2 Sep. 2019].

Kiessling T., Gutow L. and Thiel M. 2015. Marine litter as habitat and dispersal vector. In: Bergmann M., Gutow L., Klages M. (eds) Marine Anthropogenic Litter. Springer, Cham

Lamb, J., Willis, B., Fiorenza, E., Couch, C., Howard, R., Rader, D., True, J., Kelly, L., Ahmad, A., Jompa, J. and Harvell, C. 2018. Plastic waste associated with disease on coral reefs. Science, 359(6374): 460-462.

Lavers, J. and Bond, A. 2017. Exceptional and rapid accumulation of anthropogenic debris on one of the world's most remote and pristine islands. [online] Proceedings of the National Academy of Science of the United States of America. Available at: https://www.pnas.org/ content/114/23/6052 [Accessed 27 Oct. 2019].

Lee, H., Kunz, A., Shim, W. and Walther, B. 2019. Microplastic contamination of table salts from Taiwan, including a global review. Scientific Reports, $9(1)$.

LI, W., TSE, H. and FOK, L. 2016. Plastic waste in the marine environment: A review of sources, occurrence and effects. Science of The Total Environment, 566-567: 333-349.

Lloyd-Smith, M. and Immig, J. 2018. Ocean pollutants guide: toxic threats to human health and marine Life. IPEN: 70-83.

Lusher, A., McHugh, M. and Thompson, R. 2013. Occurrence of microplastics in the gastrointestinal tract of pelagic and demersal fish from the English Channel. Marine Pollution Bulletin, 67(1-2): 94-99.

Mathews, R.E. and Stretz, J. 2019. Source-To-Sea Framework For Marine Litter Prevention: Preventing Plastic Leakage From River Basins. [online] SIWI. Available at: https://www.siwi.org/wp-content/uploads/2019/08/ Marine-LitterPrevention_2019_WEBB.pdf> [Accessed 8 February 2020].

Mathews, R. E., Tengberg, A., Sjödin, J. and Liss-Lymer, B. 2019. Implementing the source-to-sea approach: A guide for practitioners. SIWI, Stockholm

Murano, C., Agnisola, C., Caramiello, D., Castellano, I., Casotti, R., Corsi, I. and Palumbo, A. 2020. How sea urchins face microplastics: Uptake, tissue distribution and immune system response. Environmental Pollution, 264: 114685.

Marinedebris.noaa.gov. 2020. Impacts | OR\&R's Marine Debris Program. [online] Available at: <https://marinedebris.noaa.gov/discover-issue/ impacts $>$ [Accessed 5 March 2020]. 
News European Parliament. (2018). Circular economy: definition, importance and benefits. [online] Available at: https://www.europarl. europa.eu/news/en/headlines/economy/20151201STO05603/circulareconomy-definition-importance-and-benefits [Accessed 23 Nov. 2019].

NOAA Fisheries. 2017. Entanglement of Marine Life: Risks and Response. [online] Available at: https://www.fisheries.noaa.gov/ insight/entanglement-marine-life-risks-and-response [Accessed 25 Nov. 2019].

OECD 2018. Improving Plastics Management: Trends, Policy Responses, And The Role Of International Co-Operation And Trade. Paris: OECD.

Oecd.org. n.d. Extended Producer Responsibility - OECD. [online] Available at: <https://www.oecd.org/env/tools-evaluation/ extendedproducerresponsibility.htm> [Accessed 1 July 2020].

Prata, J., da Costa, J., Lopes, I., Duarte, A. and Rocha-Santos, T. 2019. Effects of microplastics on microalgae populations: A critical review. Science of The Total Environment, 665: 400-405.

Preston, F. 2012. A Global Redesign? Shaping The Circular Economy. [online] The Royal Institute of International Affairs. Available at: <https://www.chathamhouse.org/publications/papers/view/182376> [Accessed 5 April 2020].

Roman, L., Hardesty, B., Leonard, G., Pragnell-Raasch, H., Mallos, N., Campbell, I. and Wilcox, C. 2020. A global assessment of the relationship between anthropogenic debris on land and the seafloor. Environmental Pollution, 264: 114663.

Romero-Hernández, O. and Romero, S. 2018. Maximizing the value of waste: From waste management to the circular economy. Thunderbird International Business Review, 60(5): 757-764.

Ryan P.G. 2015. A Brief History of Marine Litter Research. In: Bergmann M., Gutow L., Klages M. (eds) Marine Anthropogenic Litter. Springer, Cham.

Sharma, S. and Chatterjee, S. 2017. Microplastic pollution, a threat to marine ecosystem and human health: a short review. Environmental Science and Pollution Research, 24(27): 21530-21547.

SIWI. 2019. Source-To-Sea Framework For Marine Litter Prevention: Policy Brief. Available at: <https://www.siwi.org/publications/ source-to-sea-framework-formarine-litter-prevention/> [Accessed 26 March 2020].

Smith, M., Love, D., Rochman, C. and Neff, R. 2018. Microplastics in Seafood and the Implications for Human Health. Current Environmental Health Reports, 5(3): 375-386.

The Ocean Cleanup. 2020. Rivers | The Ocean Cleanup. [online] Available at: <https://theoceancleanup.com/rivers/> [Accessed 2 July 2020].

The NOAA Marine Debris Program. 2018. How Does Marine Debris Affect Coral Reefs? | OR\&R's Marine Debris Program. [online] Available at: https://blog.marinedebris.noaa.gov/how-does-marinedebris-affect-coral-reefs [Accessed 4 Feb. 2020].

Tiquio, M., Marmier, N. and Francour, P. 2017. Management frameworks for coastal and marine pollution in the European and South East Asian regions. Ocean \& Coastal Management, 135: 65-78.

Trevail, A., Gabrielsen, G., Kühn, S. and Van Franeker, J. 2015. Elevated levels of ingested plastic in a high Arctic seabird, the northern fulmar (Fulmarus glacialis). Polar Biology, 38(7): 975-981.

Unesco.org. 2017. Facts and figures on marine pollution | United Nations Educational, Scientific and Cultural Organization. [online] Available at: http://www.unesco.org/new/en/natural-sciences/ioc-oceans/focusareas/rio-20-ocean/blueprint-for-the-future-we-want/marine-pollution/ facts-and-figures-on-marine-pollution/ [Accessed 1 Nov. 2019].

Un.org. 2016. Inputs to the Secretary-General's Report on Marine Debris, Plastics and Microplastics. [online] Available at: https://www.un.org/ depts/los/general_assembly/contributions_2016/UNEP_Contribution_ to_ICP_on_marine_debris.pdf

UNEP. (n.d.). GOAL 14: Life below water. [online] Available at: https:// www.unenvironment.org/explore-topics/sustainable-developmentgoals/why-do-sustainable-development-goals-matter/goal-14 [Accessed 5 Oct. 2019].

UN Environment Programme 2001. Marine Litter- Trash That Kills. [online] Available at: https://wedocs.unep.org/bitstream/ handle/20.500.11822/9691/-Marine\%20Litter\%20-\%20trash\%20 that $\% 20$ kills -2003707 .pdf? sequence $=3 \&$ amp $\% 3$ Bis Allowed $=$ [Accessed 5 Nov. 2019].

UNEP-UN Environment Programme 2018. The State Of Plastics: World Environment Day Outlook 2018. [online] Available at: <https://www. unenvironment.org/resources/report/state-plastics-world-environmentday-outlook-2018> [Accessed 29 June 2020].

UNEP-UN Environment Programme. 2016. Marine Plastic Debris and Microplastics: Global Lessons and Research to Inspire Action and Guide Policy Change. [online] Available at: https://www. unenvironment.org/resources/report/marine-plastic-debris-andmicroplastics-global-lessons-and-research-inspire-action.

UNEP 2016. Marine Litter Legislation: A Toolkit for Policymakers. [online] Available at: https://www.unenvironment.org/resources/report/ marine-litter-legislation-toolkit-policymakers [Accessed 6 Oct. 2019].

Vegter, A., Barletta, M., Beck, C., Borrero, J., Burton, H., Campbell, M., Costa, M., Eriksen, M., Eriksson, C., Estrades, A., Gilardi, K., Hardesty, B., Ivar do Sul, J., Lavers, J., Lazar, B., Lebreton, L., Nichols, W., Ribic, C., Ryan, P., Schuyler, Q., Smith, S., Takada, H., Townsend, K., Wabnitz, C., Wilcox, C., Young, L. and Hamann, M. 2014. Global research priorities to mitigate plastic pollution impacts on marine wildlife. Endangered Species Research, 25(3): 225-247.

Winans, K., Kendall, A. and Deng, H. 2017. The history and current applications of the circular economy concept. Renewable and Sustainable Energy Reviews, 68: 825-833.

Wright, S., Thompson, R. and Galloway, T. 2013. The physical impacts of microplastics on marine organisms: A review. Environmental Pollution, 178: 483-492.

Yang, D., Shi, H., Li, L., Li, J., Jabeen, K. and Kolandhasamy, P. 2015. Microplastic pollution in table salts from China. Environmental Science \& Technology, 49(22): 13622-13627. 